\title{
Molecular mapping of loci associated with abscisic acid accumulation in triticale ( $\times$ Triticosecale Wittm.) anthers in response to low temperature stress inducing androgenic development
}

\author{
Iwona Żur • Monika Krzewska • Ewa Dubas • \\ Gabriela Gołębiowska-Pikania · Franciszek Janowiak • \\ Stefan Stojałowski
}

Received: 23 April 2012/ Accepted: 13 July 2012/Published online: 1 August 2012

(C) The Author(s) 2012. This article is published with open access at Springerlink.com

\begin{abstract}
QTLs associated with ABA content in triticale anthers were analysed using the population of $72 \mathrm{DH}$ lines derived from F1 cross between inbred line 'Saka 3006' and cv. 'Modus'. Using Windows QTL Cartographer and MapQTL 5.0 softwares, composite interval mapping (CIM) and association analysis (Kruskal-Wallis test) for ABA content before and after low temperature treatment inducing androgenic development were conducted. The concentration of ABA in freshly cut tillers varied from 0.8 to $2.2 \mathrm{nmol} \mathrm{g}^{-1} \mathrm{DW}$. Intensive ABA accumulation (up to $5.3 \mathrm{nmol} \mathrm{g}^{-1} \mathrm{DW}$ ) was observed in response to low temperature stress. No correlation between ABA concentration and androgenesis induction efficiency was detected, whereas negative correlation (up to $r=-0.33$ ) was found between concentration of ABA in anthers collected from cold treated tillers and regeneration ability. CIM analysis indicated one QTL localized on chromosome 5A $\left(\mathrm{LOD}=2.5 ; \mathrm{R}^{2}=9.3 \%\right)$ associated with ABA concentration in unstressed plants and four QTLs on chromosomes $2 \mathrm{~A}, 1 \mathrm{~B}$ and $5 \mathrm{R}$ (LOD 2.6-5.7; $\mathrm{R}^{2}=9.5-24 \%$ ) regulating $\mathrm{ABA}$ accumulation in response to low temperature stress.
\end{abstract}

I. Żur $(\bowtie) \cdot$ M. Krzewska · E. Dubas .

G. Gołębiowska-Pikania · F. Janowiak

Institute of Plant Physiology, Polish Academy of Sciences,

Niezapominajek 21, 30-239 Kraków, Poland

e-mail: zur@ifr-pan.krakow.pl

G. Gołębiowska-Pikania

Department of Genetics and Cytology, Institute of Biology, Pedagogical University, Podchorążych 2, 30-084 Kraków, Poland

\section{S. Stojałowski}

Department of Plant Genetics, Breeding and Biotechnology, West Pomeranian University of Technology, Słowackiego 17, 71-434 Szczecin, Poland
The Kruskal-Wallis test revealed significant $(p<0.01)$ association with markers localized on chromosome $4 \mathrm{~A}, 5 \mathrm{~A}$ and $2 \mathrm{RS} .3 \mathrm{R}$ for unstressed plants and on chromosomes $3 \mathrm{~A}$, $3 \mathrm{~B}, 5 \mathrm{~B}$ and $2 \mathrm{RS} .3 \mathrm{R}$ for low temperature treated plants.

Keywords ABA content - Androgenesis induction Cold stress response - Quantitative trait loci (QTL) . Winter triticale

\section{Introduction}

The process of androgenesis is an example of plant cell totipotency during which immature cells of the plant's male gametophyte (microspores) switch from the gametophytic to the sporophytic pathway of development. As a result, instead of mature pollen grains, haploid androgenic structures which resemble zygotic embryos and mimic zygotic embryo development are formed. Regenerated haploid plants and the so called doubled haploids (DH) produced from them have been advantageous in many research areas such as molecular mapping, genomics, transformation, mutation and breeding.

It is a well-known fact that the main factor responsible for the change of microspore developmental pathway is stress treatment (Touraev et al. 1997). Surprisingly, various stress factors like high or low temperature, starvation or osmotic stress can act as equivalent triggers for androgenesis induction (Zoriniants et al. 2005), suggesting a rather unspecific mechanism of its action. Among them, low temperature treatment applied to excised inflorescence, flower buds or anthers was effective in many plant species, e.g. triticale (Immonen and Robinson 2000, Pauk et al. 2000, Wędzony 2003, Zur et al. 2008). It has also been proved that androgenic development is controlled by the 
plant's genome but could be significantly modified by many environmental factors influencing physiological state and condition of the donor plant. One of the most important factors determining androgenesis effectiveness is the endogenous level of growth regulators (Wang et al. 2000, Gorbunova et al. 2001; Wassom et al. 2001). Genotype variation of this trait could be the reason for different responses to plant hormones which are applied to the induction medium. However, hormonal composition of the medium is usually designed experimentally without deeper insight into endogenous/exogenous hormone balance and its influence on the course of androgenesis (Delalonde and Coumans 1998, Wang et al. 2000, Gorbunova et al. 2001).

Abscisic acid (ABA) is the hormone involved in many physiological processes during plant growth and development. It is present in the plant organism at each developmental stage, starting from seed germination, through growth, flowering and fruit set, ending with dormancy and plant death. Among others, it regulates the expression of genes controlling the synthesis of late embryogenesis abundant (LEA) proteins (Marcotte et al. 1988; Gomez et al. 1988; Harada et al. 1989). A stimulating effect of ABA on somatic embryogenesis has been observed in in vitro cultures of many monocots (Rajasaran et al. 1987a, 1987b; Close and Ludeman 1987; Carman 1988; Brown et al. 1989; Fernando and Gamage 2000) and dicots (Zdravkovi'c-Kora'c and Neškovic 1999; Senger et al. 2001; Nishiwaki et al. 2000; Kiyosue et al. 1992; Kuo et al. 2002). ABA also plays the key role in the plant's adaptation to various environmental stresses, e.g. drought, (Wilkinson and Davies, 2002), prolonged darkness (Vaughan and Bate 1977), flooding (Zhang and Davies 1987; Jackson 1994), osmotic stress (Weiler et al. 1982), starvation (Radin et al. 1982), low temperature (Gusta et al. 2005) and pathogen attack (Cao et al. 2011) as well as in cross-tolerance to various stresses (Cutler et al. 2010; Pastori and Foyer 2002). The fact that stress treatment is the trigger for androgenic development suggests ABA involvement in microspore switch toward sporophytic pathway (Imamura and Harada 1980; Reynolds and Crawford 1996; Van Bergen et al. 1999; Wang et al. 1999; Guzman and Arias 2000).

It has been confirmed that ABA accumulation is under control of several genes and is inherited in a quantitative manner (Quarrie 1981, 1990). In recent years, results of QTL mapping for ABA accumulation in association with stress tolerance have been reported several times (Quarrie et al. 1997; Iuchi et al. 2002; You 2006). However, up to now the genetic basis of the role of ABA in androgenic development has not yet been studied.

In this study, the 'Saka 3006' $\times$ 'Modus' DH mapping population of hexaploid winter triticale $(\times$ Triticosecale Wittm.) together with its recently produced well-saturated genetic linkage map (Tyrka et al. 2011) were used to localise QTLs and to identify markers associated with ABA accumulation in triticale anthers. The $72 \mathrm{DH}$ lines used in the experiment were selected as significantly different in their androgenic responsiveness tested by anther culture method and stable in their effectiveness of androgenesis induction. Triticale spikes were cut when the majority of microspores were at the late uni-nucleated phase of development-optimal for androgenesis induction-and cold-treated for 3 weeks at $4{ }^{\circ} \mathrm{C}$. Then the anthers were isolated and transferred to in vitro culture conditions to estimate the efficiency of androgenesis induction. The ABA analysis was conducted on anthers isolated from freshly cut tillers and from low temperaturetreated tillers in which a great number of microspores had turned toward sporophytic development. The fact that the triticale population used was originally produced for drought resistance molecular mapping suggests that selected parental genotypes varied significantly with respect to endogenous ABA level and allows us to presume that its progeny segregate significantly.

\section{Materials and methods}

\section{Donor plants and growth conditions}

The seeds of $72 \mathrm{DH}$ triticale lines derived from F1 generation of a cross between inbred line 'Saka 3006' and cv. 'Modus' as well as both DH parental lines were kindly provided by Dr Eva Bauer from the State Plant Breeding Institute, Hohenheim University in Stuttgart, Germany.

Germinating seeds after 2 days in the dark at room temperature were placed in perlite pre-soaked with Hoagland's salt solution and vernalized for 7 weeks at $4{ }^{\circ} \mathrm{C}$ and $8 \mathrm{~h} / 16 \mathrm{~h}$ (day/night) photoperiod. Then the seedlings were planted into pots containing a mixture of soil, deacidified substrate peat and sand $(2 / 2 / 1 ; \mathrm{v} / \mathrm{v} / \mathrm{v})$ and grown at $20 \pm 2{ }^{\circ} \mathrm{C}, \quad 16 \mathrm{~h} / 8 \mathrm{~h}$ (day/night) photoperiod until flowering. Additional illumination (Philips $400 \mathrm{~W}$ Son-T Agro High Pressure Sodium Lamp) was applied to prolong the light period or as supplementary light during unfavourable weather conditions.

Androgenesis induction and regeneration phases

The protocol for androgenesis induction and plant regeneration has been described by Wędzony (2003) and used with several modifications. One of them was that the low temperature treatment applied to collected triticale tillers was prolonged from 2 to 3 weeks. The hormonal composition of C17 induction medium (Wang and Chen 1983) was also modified and supplemented with $0.5 \mathrm{mg} \mathrm{L}^{-1}$ 
Kinetin, $1 \mathrm{mg} \mathrm{L}^{-1}$ Dicamba and $1 \mathrm{mg} \mathrm{L}^{-1}$ Picloram. For medium gelification $0.6 \%$ agar instead of agarose was used. The cultures were incubated in the dark at $28 \pm 1{ }^{\circ} \mathrm{C}$. In the regeneration procedure low temperature stage was omitted. Regeneration phase took place at $26^{\circ} \mathrm{C}$, in the light (at about $30 \mu \mathrm{mol} \mathrm{m}{ }^{-2} \mathrm{~s}^{-1}$ during the first week, then increased to $80-100 \mu \mathrm{mol} \mathrm{m}^{-2} \mathrm{~s}^{-1}$ ) with $16 \mathrm{~h} /$ $8 \mathrm{~h}$ (day/night) photoperiod.

\section{Determination of ABA content}

The samples (anthers with total weight $0.3 \mathrm{~g}$ ) were taken from freshly cut tillers (control; C) and after low temperature treatment for 3 weeks at $4{ }^{\circ} \mathrm{C}$ (LTT) inducing the process of androgenesis. Plant material was freeze-dried and the samples were ground with ball mill MM400 (Retch, Germany) in Eppendorf vials, to which $1.5 \mathrm{ml}$ of cold distilled water was then added. The vials were then placed in boiling water for $3 \mathrm{~min}$ and shaken overnight at $4{ }^{\circ} \mathrm{C}$. The next day the extracts were centrifuged for $20 \mathrm{~min}$ in a refrigerated centrifuge at $18,000 \times g$ (MPW350R, Poland). ABA was measured in the supernatant using indirect enzyme-linked immunosorbent assay (ELISA) according to Walker-Simmons and Abrams (1991). The antibody used was MAC 252 (Babraham Technix, Cambridge, UK). Absorbance was measured by microplate reader Model 680 (Bio-Rad Laboratories, Inc.) at the wavelength of $405 \mathrm{~nm}$. For each treatment, at least four independent ELISA measurements were made on two independent samples collected from four to six different plants.

\section{Statistical analysis and QTL mapping}

There were two separate replications of the experiment. For each replication, several parameters describing the effectiveness of the induction and regeneration phases were calculated, namely: AS/100A - the number of androgenic structures produced per 100 anthers of the donor plant; $\mathrm{R} / 100 \mathrm{AS}$ - total number of regenerants per 100 androgenic structures transferred to regeneration medium; GR/ $100 \mathrm{AS}$ - the number of green regenerants per 100 androgenic structures transferred to regeneration medium; $\mathrm{R} / 100 \mathrm{~A}$ - total number of regenerants per 100 isolated anthers; GR/100A - the number of green regenerants per 100 isolated anthers. Each dish containing 100 anthers collected from one spike was assumed to be a replicate. For the majority of DH lines mean values were calculated from six replicates.

Statistical analysis of the results was performed using Statistica version 8.0 (StatSoft, Inc. USA). The normal distribution of scores was verified by Shapiro-Wilk test to validate the use of parametric tests. The effect of tested variable/variables was examined by multi-factor analysis of variance (ANOVA). Post hoc comparison was conducted using Duncan's multiple range test $(p \leq 0.05)$.

The relationship between segregations of single marker and trait was analyzed with the Kruskal-Wallis test $(\mathrm{K}-\mathrm{W})$ using MapQTL 5.0 package (Van Ooijen 2004). Linkage analysis was performed using the composite interval mapping (CIM) method with Windows QTL Cartographer version 2.5 (Wang et al. 2007). Threshold LOD scores were calculated by 1,000 permutations. The percentage of phenotypic variation was calculated with a single factor regression $\left(\mathrm{R}^{2}\right)$. The CIM and Kruskal-Wallis test analyses were performed separately for each experimental replication.

\section{Results}

Androgenesis induction and regeneration efficiency

Significant variation in all components of androgenic responsiveness (androgenic structure induction, total plant regeneration and green plant regeneration ability) was observed between parental genotypes and among their F1 cross derived offspring population.

The mean androgenesis induction efficiency (AS/100A) of DH 'Modus' was more than two times higher in comparison with DH 'Saka 3006' (Table 1). Thus, although mean total and green plant regeneration abilities were similar for 'Saka 3006' and 'Modus' (10.5 versus 13.6 $\mathrm{R} / 100 \mathrm{AS}$ and 4.6 versus $5.5 \mathrm{GR} / 100 \mathrm{AS}$, respectively), the values of parameters characterizing final androgenesis efficiency (R/100A and GR/100A) for paternal genotype 'Modus' were 3.5 times higher than for 'Saka 3006'. In the studied DH progeny population a much wider variation with extremes significantly exceeding characteristics of parental genotypes both in plus and in minus was observed (Table 1).

Endogenous level of ABA and its modifications in response to low temperature treatment

Variation analysis showed significant influence $(p \leq 0.001)$ of both genotype and low temperature tillers treatment on ABA concentration in anthers of 72 triticale DH lines. The effect of interaction between variables was also significant (Table 2).

The results received for parental genotypes and the population of their progeny is shown in Table 3. Statistical analysis (Duncan test, $p \leq 0.05$ ) did not indicate significant differences between parental DH lines with respect to ABA concentration in anthers isolated from freshly cut tillers. However, they varied dramatically in their reaction 
Table 1 Mean efficiency of androgenesis in parental triticale genotypes (DH 'Saka 3006', DH 'Modus') and a population of 72 DH lines derived from their F1 cross

\begin{tabular}{lcccccc}
\hline Trait & DH Saka 3006 & DH Modus & \multicolumn{2}{l}{ Offspring DH population } & \\
\cline { 5 - 7 } & Mean \pm SD & Mean \pm SD & Mean \pm SD & Range & Skewness & Kurtosis \\
\hline AS/100A & $55.0 \pm 21.2$ & $123.8 \pm 25.4$ & $85.6 \pm 6.1$ & $6-222$ & 0.57 & -0.18 \\
R/100AS & $10.5 \pm 3.0$ & $13.6 \pm 2.2$ & $15.3 \pm 0.7$ & $2-29$ & 0.27 & -0.29 \\
GR/100AS & $4.6 \pm 2.1$ & $5.5 \pm 2.0$ & $8.1 \pm 0.5$ & $0-18$ & 0.35 & 1.18 \\
R/100A & $4.6 \pm 1.2$ & $16.4 \pm 5.0$ & $10.4 \pm 0.7$ & $0-35$ & 2.32 \\
GR/100A & $2.0 \pm 1.0$ & $7.1 \pm 2.5$ & $5.8 \pm 0.6$ & $0-30$ & 8.98 \\
\hline
\end{tabular}

The data are the means of two separate experimental replications with 6 replication (plates containing 100 anthers) each. The offspring DH population is also characterized by the extremes range (min-max) and parameters of data distribution (skewness and kurtosis). AS/100A, the number of androgenic structures (AS) produced per 100 anthers (A) of the parent plant; R/100A, total number of regenerants (R) per 100 anthers (A); R/100AS, total number of regenerants (R) per 100 androgenic structures (AS) transferred to the regeneration medium; GR/100A, number of green regenerants (GR) per 100 anthers (A); GR/100AS, number of green regenerants (GR) per 100 androgenic structures (AS) transferred to the regeneration medium

Table 2 Effect of tested variables on ABA concentration in anthers of $72 \mathrm{DH}$ lines of winter triticale mapping population 'Saka 3006 ' $\times$ 'Modus'

\begin{tabular}{lrrrrl}
\hline Sources of variation & \multicolumn{1}{l}{ SS } & $d f$ & $M S$ & \multicolumn{1}{l}{$F$} & $p$ \\
\hline (1) Genotype of maternal plant & 144.0 & 71 & 2.0 & \multicolumn{1}{c}{6.04} & $* * *$ \\
(2) Tillers treatment & 111.2 & 1 & 111.2 & 331.4 & $* * *$ \\
$(1) \times(2)$ & 89.7 & 71 & 1.3 & 3.761 & $* * *$ \\
\hline
\end{tabular}

$S S$ sum of squares, $d f$ degrees of freedom, $M S$ mean square, $F$ statistic in ANOVA, $p$ probability, $* * * p \leq 0.001$

to low temperature treatment ( 3 weeks at $4{ }^{\circ} \mathrm{C}$ ). In anthers of the maternal genotype 'Saka 3006' ABA concentration did not change significantly (23\% increase of the initial value), whereas in anthers of 'Modus' ABA concentration increased almost three times in comparison with the value of control plants (Table 3).

In the studied DH population very large variation was observed for both examined traits (Table 3 ). The concentration of $\mathrm{ABA}$ in freshly cut tillers varied from 0.8 to

Table 3 Mean abscisic acid (ABA) concentration ( $\mathrm{nmol} \mathrm{g}^{-1} \mathrm{DW}$ ) in anthers of $72 \mathrm{DH}$ lines of winter triticale mapping population 'Saka 3006 ' $\times$ 'Modus' and their parental DH lines

\begin{tabular}{lllll}
\hline Trait & 'Saka 3006' & 'Modus' & \multicolumn{2}{c}{ 'Saka 3006' $\times$ 'Modus' } \\
\cline { 4 - 5 } & Mean $\pm \mathrm{SD}$ & & Mean $\pm \mathrm{SD}$ & Range \\
\hline $\mathrm{ABA} / \mathrm{C}$ & $1.18 \pm 0.12$ & $1.42 \pm 0.09$ & $1.41 \pm 0.3$ & $0.80-2.2$ \\
$\mathrm{ABA} / \mathrm{LTT}$ & $1.52 \pm 0.09$ & $4.13 \pm 1.13$ & $2.26 \pm 0.8$ & $1.06-5.28$ \\
\hline
\end{tabular}

The data are the means from at least four independent measurements made on two independent samples collected from four to six different plants \pm SD. The offspring $\mathrm{DH}$ population is characterized by the mean value $\pm \mathrm{SD}$, and the extremes range $(\min -\max ) . \mathrm{ABA} / \mathrm{C}, \mathrm{ABA}$ concentration in anthers collected from freshly cut tillers; ABA/LTT, ABA concentration in anthers after low temperature treatment (3 weeks at $4{ }^{\circ} \mathrm{C}$ )
$2.2 \mathrm{nmol} \mathrm{g}^{-1}$ DW with a population mean of $1.41 \mathrm{nmol} \mathrm{g}^{-1} \mathrm{DW}$-almost identical with that of the paternal genotype 'Modus'. Generally, in the studied population low temperature treatment significantly increased $\mathrm{ABA}$ concentration, with a mean increase of 1.5. The range of variation (from 1.1 to $5.3 \mathrm{nmol} \mathrm{g}^{-1} \mathrm{DW}$ ) in ABA concentration among DH population exceeded the variation between parental genotypes. The distribution of both traits was near to normal, skewed slightly towards the lower part of the frequency scale (Fig. 1). However, as no procedure of data transformation resulted in more normal distribution, the original data was used for further analysis. The mean results for all DH lines are shown in Fig. 2.

Correlation analysis did not show significant association between ABA concentration in anthers isolated from freshly cut tillers and androgenesis induction efficiency (AS/100A; Table 4). Similarly, the effectiveness of androgenesis induction was related neither to ABA concentration in anthers isolated from low temperature treated tillers nor to the increase of $\mathrm{ABA}$ concentration $(\triangle \mathrm{ABA})$ in reaction to low temperature treatment. Moreover, weak/ moderate but statistically significant negative correlation ( $r=-0.31$ to -0.33 ) was found between concentration of $\mathrm{ABA}$ in anthers collected from cold treated tillers and regeneration ability (GR/100A, R/100AS).

\section{Analysis of QTL associated with ABA concentration} in triticale anthers

QTL analyses were performed separately for each replication but here only consistent results are presented, confirmed in both experiments.

QTL analysis detected quite different localization of genes associated with ABA concentration in anthers collected from control, non-stressed and cold-treated tillers. 

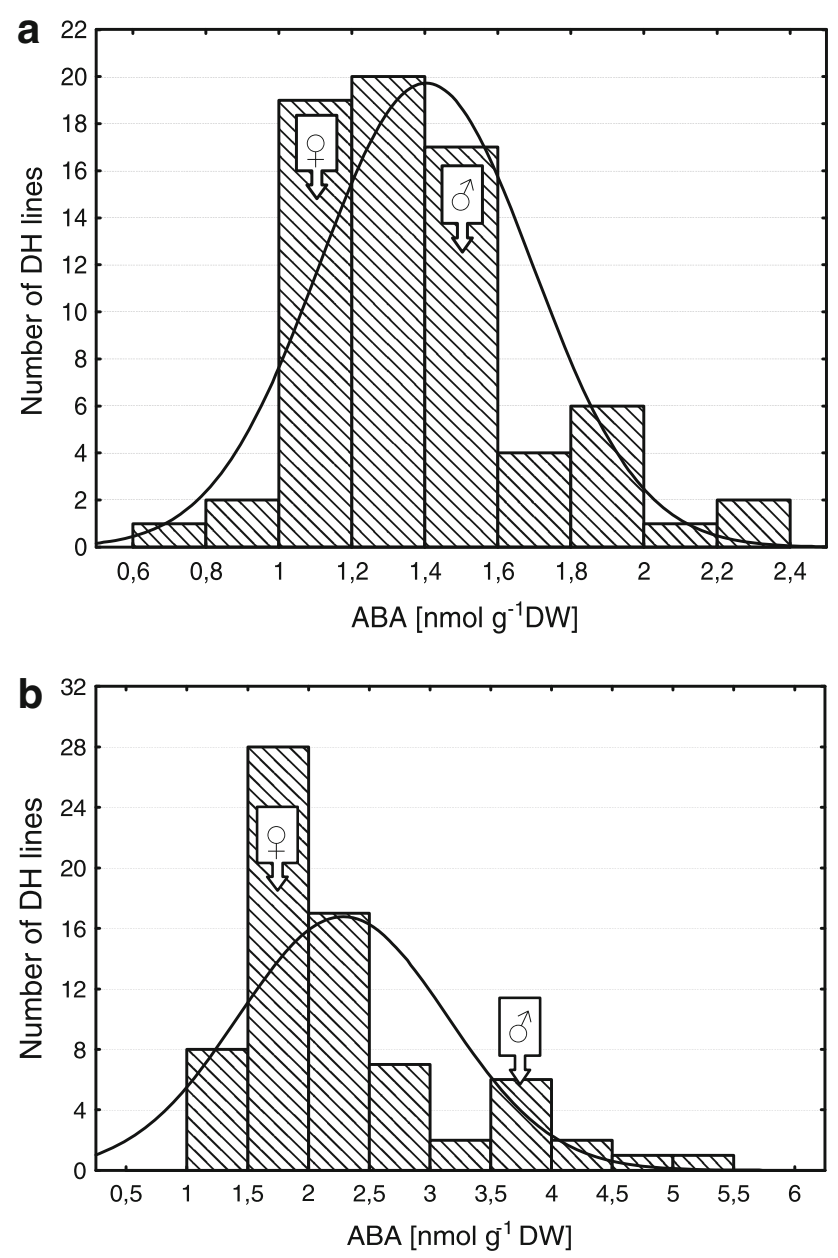

Fig. 1 Frequency distribution of $\mathrm{ABA}$ concentration in anthers isolated from a freshly cut tillers and $\mathbf{b}$ low temperature treated tillers $\left(3\right.$ weeks at $4{ }^{\circ} \mathrm{C}$ ) of 'Saka 3006' $\times$ 'Modus' DH mapping population of hexaploid winter triticale. Arrows indicate the values for: 으'Saka 3006' and \$-'Modus'

CIM analysis localized only one QTL associated with ABA concentration in control plants and four QTLs regulating ABA accumulation in response to low temperature stress. All chromosome regions detected by CIM method were confirmed by the Kruskal-Wallis test $(p<0.01)$ as carrying markers significantly associated with the studied traits.

Loci associated with ABA concentration in anthers collected from control plant were localized on the fifth chromosome of wheat subgenome A (Table 5). It explained about $9 \%$ of the phenotypic variation and the positive effect originated from 'Modus' allele. The Kruskal-Wallis test revealed an additional significant $(p<0.01)$ association with markers localized on chromosome 4A and two more on chromosomes 5A and 2RS.3R (Table 6).

QTLs controlling ABA accumulation in response to low temperature treatment were identified on chromosomes $2 \mathrm{~A}$, $1 \mathrm{~B}$ and 5R (Table 5). The highest effect (LOD 5.7 and $\mathrm{R}^{2}$ $23.8 \%$ ) came from QTL on chromosome $5 \mathrm{R}$ and only in this case 'Saka 3006' allele increased the value of the trait. The most likely position of genes significantly $(p<0.01)$ associated with the trait was the interval between $r P t$ $505701(97.2 \mathrm{cM})$ and $r P t-400221(98.2 \mathrm{cM})$ markers. Despite lower LOD value (2.6-3.1), two QTLs mapped on chromosome 2A flanked by the marker loci Xwmc522Xgwm0372 and tPt-8937-wPt-3244 as well as one QTL on chromosome 1B between $w P t-4129$ and $r P t-5412$ loci were detected consistently by both analytical methods and explained $9.5-13.3 \%$ of the phenotypic variation (Table 5). The Kruskal-Wallis test identified additional significantly $(p<0.01)$ associated markers on chromosomes 3A, 3B, 5B and 2RS.3R, details shown in Table 6.

\section{Discussion}

The hypothesis suggesting an involvement of $\mathrm{ABA}$ in microspore reprogramming and androgenic development has been put forward in a number of reports. Strong positive correlation between ABA concentration and microspore viability has been detected in isolated microspore cultures of barley (Van Bergen et al. 1999; Wang et al. 1999). Moreover, the number of binucleated microspores was diminished suggesting an involvement of ABA in the repression of gametophytic development (Van Bergen et al. 1999). Similarly, Reynolds and Crawford (1996) reported significant correlation between ABA accumulation and the expression of early cysteine-labeled metallothionein gene, which was considered the marker for an early phase of androgenesis induction. The role of ABA in the activation of mitogen-activated protein kinase cascades initiating microspore divisions and differentiation was also suggested (Préstamo et al. 1999; Liu 2012). Positive effect of ABA has been observed in androgenic cultures of tobacco (Imamura and Harada 1980; Kyo and Harada 1985), barley (Van Bergen et al. 1999), wheat (Hu et al. 1995) and rice (Guzman and Arias 2000). Moreover, inhibition of ABA synthesis significantly decreased the effectiveness of androgenesis (Hoekstra et al. 1997; Reynolds and Crawford 1996). Our earlier investigations indicated that triticale varieties differing in androgenic responsiveness also significantly differ in endogenous ABA level (Żur et al. 2008). Viability of microspores isolated from freshly cut tillers of the cultivar with low endogenous ABA rapidly decreased during the first days of in vitro culture. Microspores of the cultivar with relatively high $\mathrm{ABA}$ concentration were more tolerant to the stress associated with isolation and transfer to in vitro culture, which resulted in higher effectiveness of androgenesis induction.

A significant increase in ABA concentration in response to low temperature treatment was observed in anthers of the tested triticale DH lines. This reaction is a very typical 


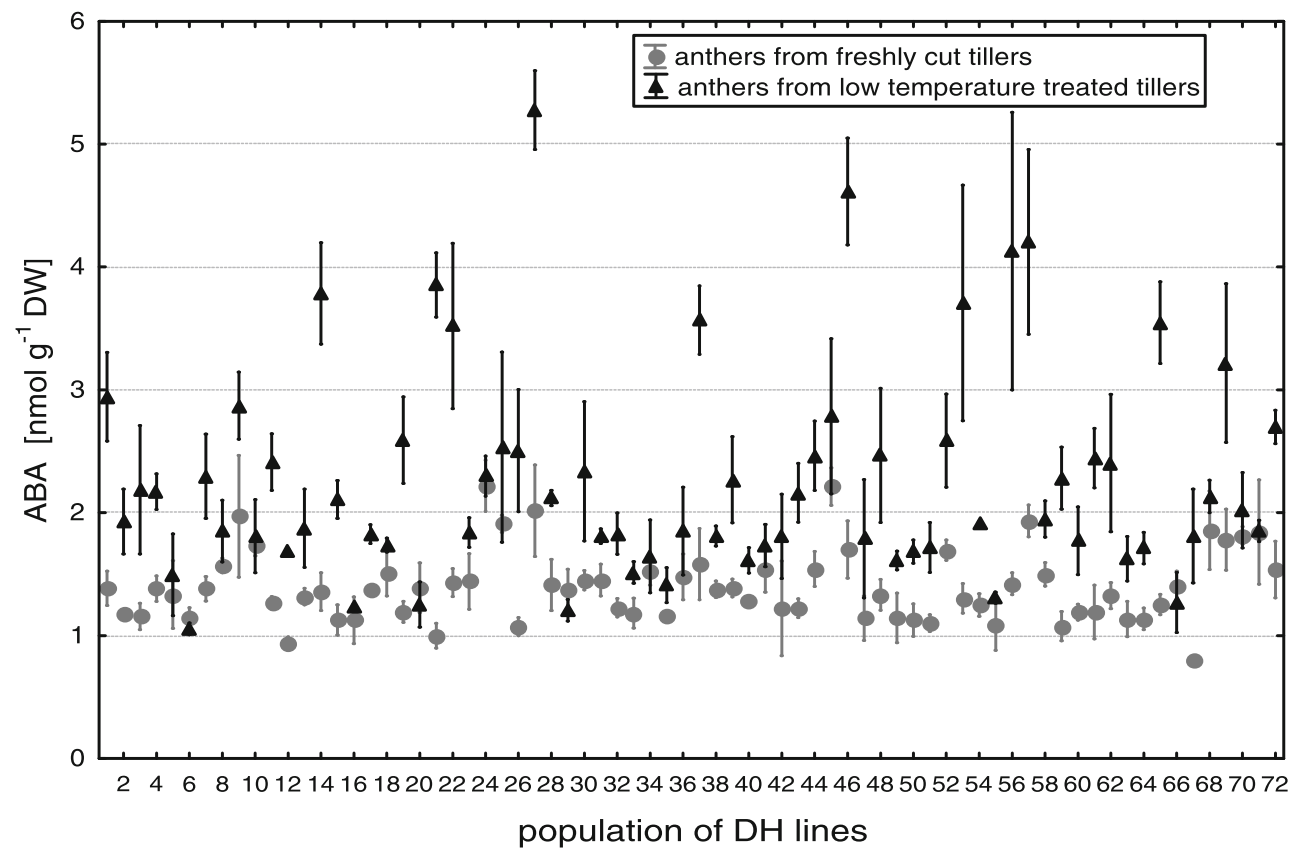

Fig. 2 Abscisic acid concentration (nmol g ${ }^{-1}$ DW) in anthers isolated from freshly cut tillers and low temperature treated tillers ( 3 weeks at $4{ }^{\circ} \mathrm{C}$ ) of 'Saka 3006' $\times$ 'Modus' DH mapping population of hexaploid winter triticale. DH lines were ranked according to

Table 4 Correlation (r) between ABA concentration in triticale anthers and various parameters characterizing androgenesis efficiency for $72 \mathrm{DH}$ lines of triticale mapping population 'Saka3006' $\times$ 'Modus'

\begin{tabular}{clllll}
\hline & AS/ & R/ & GR/ & R/ & GR/ \\
& $100 \mathrm{~A}$ & 100AS & 100AS & \multicolumn{1}{c}{$100 \mathrm{~A}$} & \multicolumn{1}{c}{$100 \mathrm{~A}$} \\
\hline ABA/C & 0.14 & -0.05 & 0.04 & 0.17 & 0.18 \\
ABA/ & 0.12 & $-\mathbf{0 . 3 3}$ & $-\mathbf{0 . 3 1}$ & -0.13 & -0.15 \\
LTT & & & & & \\
$\Delta \mathrm{ABA}$ & 0.06 & -0.30 & $\mathbf{- 0 . 3 3}$ & -0.22 & -0.25 \\
\hline
\end{tabular}

$\mathrm{ABA} / \mathrm{C}, \mathrm{ABA}$ concentration in anthers collected from freshly cut tillers; ABA/LTT, ABA concentration in anthers after low temperature treatment ( 3 weeks at $\left.4{ }^{\circ} \mathrm{C}\right) ; \triangle \mathrm{ABA}, \mathrm{ABA}$ accumulation induced by low temperature treatment $(\triangle \mathrm{ABA}=\mathrm{ABA} / \mathrm{LTT}-\mathrm{ABA} / \mathrm{C})$; $\mathrm{AS} /$ $100 \mathrm{~A}$, the number of androgenic structures produced per 100 anthers of the donor plant; R/100AS, total number of regenerants per 100 androgenic structures transferred to regeneration medium; GR/ $100 \mathrm{AS}$, the number of green regenerants per 100 androgenic structures transferred to regeneration medium; R/100A, total number of regenerants per 100 isolated anthers; GR/100A, the number of green regenerants per 100 isolated anthers; r, correlation coefficient; values in bold characters mark significant correlation

biochemical response to a wide spectrum of stress factors. Similar to the results obtained on wheat by Ji et al. (2011), the parental genotype more tolerant to drought ('Saka 3006') accumulated less ABA in comparison with the more sensitive genotype ('Modus'). Such a result seems to confirm the hypothesis of Imamura and Harada (1980) that androgenesis induction requires a specific threshold of increasing effectiveness of androgenesis induction (AS/100A). Data are mean \pm SD of four independent ELISA measurements performed on two independent experimental replications (anthers collected from four to six different plants with total weight of about $0.3 \mathrm{~g} \mathrm{FW}$ )

ABA level. The positive influence of ABA could be explained by increased activity of antioxidative system protecting isolated microspores during transfer and first days of in vitro culture. Such effects as increased level of hydrogen peroxide $\left(\mathrm{H}_{2} \mathrm{O}_{2}\right)$, stimulation of antioxidative enzyme activity as well as low-molecular antioxidant compounds accumulation were observed in response to exogenous ABA application (Jiang and Zhang 2001; Agarwal et al. 2005).

However, the results received in the present study did not confirm direct linear correlation between the efficiency of androgenesis induction (AS/100A) and ABA concentration in triticale anthers. This concerned both anthers collected from freshly cut tillers of control plants growing in physiologically optimal glasshouse conditions and anthers collected from tillers at the end of androgenesisinducing cold-temperature treatment ( 3 weeks at $4{ }^{\circ} \mathrm{C}$ ). Surprisingly, weak/moderate but significant negative correlation between the concentration of $\mathrm{ABA}$ in anthers collected from cold-treated tillers and both parameters of regeneration efficiency (GR/100AS, R/100AS) was detected. It seems that higher ABA concentration not only did not influence microspore reprogramming but had a negative effect on androgenic structure formation and regeneration ability. A similar negative ABA effect was observed in anther culture of Brussels sprouts (Biddington et al. 1992). It was also reported that male sterility in rice induced by low temperature was associated with intensive 
Table 5 Identification and molecular localization of loci of ABA concentration in anthers isolated from freshly cut tillers $(\mathrm{ABA} / \mathrm{C})$ and after low temperature treatment $\left(3\right.$ weeks at $\left.4{ }^{\circ} \mathrm{C} ; \mathrm{ABA} / \mathrm{LTT}\right)$ for

\begin{tabular}{|c|c|c|c|c|c|c|c|}
\hline \multirow[t]{2}{*}{ Trait } & \multirow[t]{2}{*}{ Loci QTL } & \multirow[t]{2}{*}{ Flanking markers } & \multirow[t]{2}{*}{ LOD } & \multirow[t]{2}{*}{$\mathrm{R}^{2}(\%)$} & \multirow[t]{2}{*}{ Add } & \multicolumn{2}{|c|}{ Marker associated with QTL by $\mathrm{K}-\mathrm{W}$ test } \\
\hline & & & & & & Name & $p$ \\
\hline $\mathrm{ABA} / \mathrm{C}$ & QAfrsm-5A & Xcfa2163 (77.7)-Xgwm0595 (96.0) & 2.5 & 9.3 & -0.10 & wPt-8262 & $* * *$ \\
\hline \multirow[t]{4}{*}{ ABA/LTT } & QAchsm-2A-1 & Xwmc522 (56.1)-Xgwm0372 (68.4) & 2.6 & 9.5 & -0.26 & wPt-5251 & $* * * *$ \\
\hline & QAchsm-2A-2 & $t P t-8937$ (75.0)-wPt-3244 (80.6) & 3.1 & 13.3 & -0.38 & tPt-8937 & $* * * * *$ \\
\hline & QAchsm-1B & $w P t-4129$ (116.6)-rPt-5412 (124.5) & 3.0 & 12.8 & -0.38 & $\mathrm{rPt}-5412$ & $* * *$ \\
\hline & QAchsm-5R & $r P t-505701(97.2)-r P t-400221(98.2)$ & 5.7 & 23.8 & 0.80 & rPt-505701 & $* * * *$ \\
\hline
\end{tabular}

LOD, logarithm of the odds for peaked marker; $\mathrm{R}^{2}$, \% of phenotypic variance explained by the QTL, Add, additive effect of the 'Saka 3006' allele; ***, ****, ***** $p<0.01,0.005,0.001$, respectively

Table 6 Genomic regions significantly associated with regulation of ABA concentration (nmol g $\left.{ }^{-1} \mathrm{DW}\right)$ in anthers collected from freshly cut tillers $(\mathrm{ABA} / \mathrm{C})$ and after low temperature treatment (3 weeks at $\left.4{ }^{\circ} \mathrm{C}\right)(\mathrm{ABA} / \mathrm{LTT})$ identified by Kruskal-Wallis test for winter triticale $(\times$ Triticosecale Wittm. $)$ mapping population 'Saka 3006 ' $\times$ 'Modus'

\begin{tabular}{llll}
\hline Trait & Chromosome & Flanking markers (cM) & $p$ \\
\hline ABA/C & 4A & $w P t-3605(87)-X g w m 0160(97)$ & $* * * * *$ \\
& 5A & $\begin{array}{l}\text { Xgwm0595 (96)-Xgwm0291 } \\
(109)\end{array}$ & $* * * *$ \\
& & $r P t-509415(79)-r P t-506986$ & $* * *$ \\
& 2RS.3R & $(80)$ & \\
& & $w P t-9761(125)-w P t-1339(130)$ & $* * * *$ \\
ABA/ & 3A & $w P t-9422(127)-r P t-390444$ & $* * *$ \\
LTT & 3B & $(128)$ & \\
& & $w P t-0498(88)-X b a r c 140(92)$ & $* * * *$ \\
& 5B & $r P t-507299(126)-t P t-513724$ & $* * *$ \\
& 2RS.3R & $(127)$ &
\end{tabular}

$p$, The highest level of probability in Kruskal-Wallis test; $* * *, * * * *$, $* * * * * p<0.01,0.005,0.001$

ABA accumulation (Oliver et al. 2007). The same correlation was noted in the case of drought-induced male sterility in wheat (Ji et al. 2011). Moreover, it was proved that ABA spike treatment mimics the effect of cold and drought causing plant sterility. The mechanism of ABA action was connected with the repression of OsINV4, the anther wall invertase activity regulator, and the reduction of anther sink strength (Oliver et al. 2005, 2007).

The results of QTL analysis indicate quite different localization of genes controlling ABA content in anthers collected from plants growing in physiologically optimal conditions in comparison with cold-stressed plants.

QTL analysis confirmed the location of gene(s) associated with $\mathrm{ABA}$ concentration in non-stressed conditions on chromosome $5 \mathrm{~A}$ with the most likely position in the region flanked by loci Xcfa2163 and Xgwm0595. Chromosome 5A was earlier indicated as carrying genes regulating drought- winter triticale $(\times$ Triticosecale Wittm.) mapping population 'Saka 3006 ' $\times$ 'Modus' by the use of CIM method and Kruskal-Wallis $(\mathrm{K}-\mathrm{W})$ test 
chromosome $3 \mathrm{~B}$ as possessing genes controlling seed dormancy. Also the results of the study examining rye grains responsiveness to ABA (Milczarski and Masojć 2002) support our data as the QTLs controlling the trait were identified on chromosomes $1 \mathrm{RS}, 2 \mathrm{RS}$ and 5RL, with the last one having the strongest effect.

In the studied triticale DH population, among QTLs associated with ABA concentration in control plants, two regions on chromosome $5 \mathrm{~A}$ located very close to locus QASsm-5A-1 determined androgenic induction ability Krzewska et al. (in press). Next two loci on chromosome 4A were situated nearby locus QGRASsm-4A-2, which was associated with green plant regeneration efficiency, whereas locus on chromosome 5R was localized nearby loci regulating final androgenesis effectiveness expressed in total $(\mathrm{R} / 100 \mathrm{~A})$ and green $(\mathrm{GR} / 100 \mathrm{~A})$ regenerants number [rPt-506739, rPt-505701, and Xrems1063, rPt-400221 respectively; Krzewska et al. (in press)].

In conclusion, the obtained results show ABA accumulation in response to stress treatment induces androgenic development. Increased ABA concentration could sustain microspore viability by an improvement of its tolerance or adaptation to the stress connected with isolation procedure and transfer to in vitro culture as it was suggested by Imamura and Harada (1980). However, the lack of correlation between ABA accumulation and androgenesis induction efficiency together with negative correlation with androgenic structure regeneration ability suggest complex, non-linear character of the relation with specific thresholds of positive effect. On the other hand, another explanation can also be suggested: close location of genes having a major effect on ABA accumulation and controlling androgenesis effectiveness could be the reason for the observed association without direct physiological relationship between both traits. To draw more detailed conclusions, an in-depth analysis with the use of exogenous/ endogenous ABA balance manipulation is necessary.

Acknowledgments The research was conducted in the frame of COST Action FA0604 'Triticeae genomics for the advancement of essential European crops (TritiGen)' and supported by the Polish Ministry of Science and Higher Education (research project $548 / \mathrm{N}$ COST/2009/0).

Open Access This article is distributed under the terms of the Creative Commons Attribution License which permits any use, distribution, and reproduction in any medium, provided the original author(s) and the source are credited.

\section{References}

Agarwal S, Sairam RK, Srivastava GC, Tyagi A, Meena RC (2005) Role of ABA, salicylic acid, calcium and hydrogen peroxide on antioxidant enzymes induction in wheat seedlings. Plant Sci 169:559-570
Biddington NL, Sutherland RA, Robinson HT (1992) The effects of gibberellic acid, fluridone, abscisic acid, and paclobutrazol on anther culture of brussels sprouts. Plant Growth Regul 11:81-84

Brown C, Brooks FJ, Pearson D, Mathias RJ (1989) Control of embryogenesis and organogenesis in immature wheat embryo callus using increased medium osmolarity and abscisic acid. J Plant Physiol 133:727-733

Cao FY, Yoshioka K, Desveaux D (2011) The roles of ABA in plantpathogen interactions. J Plant Res 124:489-499

Carman JG (1988) Improved somatic embryogenesis in wheat by partial simulation of the in-ovulo oxygen, growth-regulator and desiccation environments. Planta 175:417-424

Chen C-X, Cai S-B, Bai G-H (2008) A major QTL controlling seed dormancy and pre-harvest sprouting resistance on chromosome 4A in a Chinese wheat landrace. Mol Breed 21:351-358

Close KR, Ludeman LA (1987) The effect of auxin-like plant growth regulators and osmotic regulation on induction of somatic embryogenesis from elite maize inbreds. Plant Sci 52:81-89

Cutler SR, Rodriguez PL, Finkelstein RR, Abrams SR (2010) Abscisic acid: emergence of a core signaling network. Ann Rev Plant Biol 61:651-679

Delalonde M, Coumans MP (1998) Effect of IAA content modulators on peroxidase activity and on endogenous IAA during cold pretreatment of maize anthers prior to androgenesis. Plant Growth Reg 26:123-130

Fernando SC, Gamage CKA (2000) Abscisic acid induced somatic embryogenesis in immature embryo explants of coconut (Cocos nucifera L.). Plant Sci 151:193-198

Gomez J, Sanchez-Martinez D, Stiefel V, Rigau J, Puigdomenech P, Pages M (1988) A gene induced by the plant hormone abscisic acid in response to water stress encodes a glycine-rich protein. Nature 334:262-264

Gorbunova VJ, Kruglova NN, Abramov SN (2001) The induction of androgenesis in vitro in spring soft wheat. Balance of exogenus and endogenous phytohormones. Biol Bull 28(1):25-30

Gusta LV, Trischuk R, Weiser CJ (2005) Plant cold acclimation: the role of abscisic acid. J Plant Growth Regul 24:308-318

Guzman M, Arias FJZ (2000) Increasing anther culture efficiency in rice (Oryza sativa L.) using anthers from ratooned plants. Plant Sci 151:107-114

Harada H, Delisle A, Bader C, Crouch M (1989) Unusual sequences of an abscisic acid-inducible mRNA which accumulates late in Brassica napus development. Plant Mol Biol 12:349-401

Hoekstra S, van Bergen S, van Brouwershaven IR, Schilperoort RA, Wang M (1997) Androgenesis in Hordeum vulgare L.: effects of mannitol, calcium and abscisic acid on anther pretreatment. Plant Sci 126:211-218

$\mathrm{Hu}$ TC, Ziauddin A, Simion E, Kasha KJ (1995) Isolated microspore culture of wheat (Triticum aestivum L.) in a defined media I. Effects of pretreatment, isolation methods and hormones. In Vitro Cell Dev Biol 31:79-83

Imamura J, Harada H (1980) Effects of abscisic acid and water stress on the embryo and plantlet production in anther culture of Nicotiana tabacum cv. Samsun. Z. Pflanzenphysiol 100:285289

Immonen S, Robinson J (2000) Stress treatments and ficoll for improving green plant regeneration in triticale anther culture. Plant Sci 150:77-84

Iuchi S, Kobayashi M, Taji T, Naramoto M, Seki M, Kato T, Tabata S, Kakubari Y, Qin XQ, Zeevaart JAD (2002) Overexpression of a 9-cis-epoxycarotenoid-dioxygenase gene in Nicotiana plumbaginifolia increases abscisic acid and phaseic acid levels and enhances drought tolerance. Plant Physiol 128(2):544-551

Jackson MB (1994) Root-to-shoot communication in flooded plants involvement of abscisic acid, ethylene, and 1-aminocyclopropane-1-carboxylic acid. Agron J 86:775-782 
Ji X, Dong B, Shiran B, Talbot MJ, Edlington JE, Hughes T, White RG, Gubler F, Dolferus R (2011) Control of abscisic acid catabolism and abscisic acid homeostasis is important for reproductive stage stress tolerance in cereals. Plant Physiol 156:647-662

Jiang MY, Zhang JH (2001) Effect of abscisic acid on active oxygen species, antioxidative defence system and oxidative damage in leaves of maize seedlings. Plant Cell Physiol 42:1265-1273

Kato K, Nakamura W, Tabiki T, Miura H, Sawada S (2001) Detection of loci controlling seed dormancy on group 4 chromosomes of wheat and comparative mapping with rice and barley genomes. Theor Appl Genet 102:980-998

Kiyosue T, Nakajima M, Yamaguchi I, Satoh S, Kamada H, Harada H (1992) Endogenous levels of abscisic acid in embryogenic cells, non-embryogenic cells and somatic embryos of carrot (Daucus carota L.). Biochem Physiol Pfl 188:343-347

Krzewska M, Czyczyło-Mysza I, Dubas E, Gołębiowska-Pikania G, Golemiec E, Stojałowski S, Chrupek M, Żur I (in press) Quantitative trait loci associated with androgenic responsiveness in triticale $(\times$ Triticosecale Wittm. $)$ anther culture. Plant Cell Rep

Kuo C-L, Sagare AP, Lo S-F, Lee C-Y, Chen C-C, Tsay H-S (2002) Abscisic acid promotes development of somatic embryos on converted somatic embryos of Corydalis yanhusuo (Fumariaceae). J Plant Physiol 159:423-427

Kyo M, Harada H (1985) Studies on conditions for cell division and embryogenesis in isolated pollen culture of Nicotiana rustica. Plant Physiol 79:90-94

Liu Y (2012) Roles of mitogen-activated protein kinase cascades in ABA signaling. Plant Cell Rep 31:1-12

Marcotte WR, Bayley CC, Quatrano RS (1988) Regulation of a wheat promotor by abscisic acid in rice protoplasts. Nature 335: 454-457

Mares DJ, Mrva K, Cheong J, Williams K, Watson, Storlie E, Sutherland M, Zou Y (2005) A QTL located on chromosome 4A associated with dormancy in white- and redgrained wheats of diverse origin. Theor Appl Genet 111:1357-1364

Milczarski P, Masojć P (2002) The mapping of QTLs for chlorophyll content and responsiveness to gibberellic (GA3) and abscisic (ABA) acids in rye. Cell Mol Biol Lett 7:449-455

Nishiwaki M, Fujino K, Koda Y, Masuda K, Kikuta Y (2000) Somatic embryogenesis induced by the simple application of abscisic acid to carrot (Daucus carota L.) seedling in culture. Planta 211:756-759

Noda K, Matsuura T, Maekawa M, Taketa S (2002) Chromosomes responsible for sensitivity of embryo to abscisic acid and dormancy in wheat. Euphytica 123:203-209

Oliver SN, Van Dongen JT, Alfred SC, Mamun EA, Zhao XC, Saini HS, Fernandes SF, Blanchard CL, Sutton BG, Geigenberger P (2005) Cold-induced repression of the rice anther-specific cell wall invertase gene OSINV4 is correlated with sucrose accumulation and pollen sterility. Plant Cell Environ 28:15341551

Oliver SN, Dennis ES, Dolferus R (2007) ABA regulates apoplastic sugar transport and is a potential signal for cold-induced pollen sterility in rice. Plant Cell Physiol 48:1319-1330

Pastori GM, Foyer CH (2002) Common components, networks, and pathways of cross-tolerance to stress. The central role of "redox" and abscisic acid-mediated controls. Plant Physiol 129: 460-468

Pauk J, Puolimatka M, Tók L, Monostori T (2000) In vitro androgenesis of triticale in isolated microspore culture. Plant Cell Tiss Org Cult 61:221-229

Préstamo G, Testillano PS, Vicente O, Gonzales-Melendi P, Coronado MJ, Wilson C, Heberle-Bors E, Risueno MC (1999) Ultrastructural distribution of a MAP kinase and transcripts in quiescent and cycling plant cells and pollen grains. J Cell Sci 112:1065-1076

Quarrie SA (1981) Genetic variability and heritability of drought induced abscisic acid accumulation in spring wheat. Plant Cell Environ 4:147-151

Quarrie SA (1990) Modifying drought responses of wheat by selecting for genetic variation in abscisic acid production. Savremena Poljoprivreda 38:101-109

Quarrie SA, Gulli M, Calestani C, Steed A, Marmiroli N (1994) Location of a gene regulating drought-induced abscisic acid production on the long arm of chromosome 5A of wheat. Theor Appl Genet 89:794-800

Quarrie SA, Laurie DA, Zhu J, Lebreton C, Semikhodskii A, Steed A, Witsenboer H, Calestani C (1997) QTL analysis to study the association between leaf size and abscisic acid accumulation in droughted rice leaves and comparisons across cereals. Plant Mol Biol 35(1-2):155-165

Radin JW, Parker LL, Guinn G (1982) Water relations of cotton plants under nitrogen deficiency. V. Environmental control of abscisic acid accumulation and stomatal sensitivity to abscisic acid. Plant Physiol 70:1066-1070

Rajasekaran K, Hein MB, Vasil IK (1987a) Endogenous abscisic acid and indolile-3-acetic acid and somatic embryogenesis in cultured leaf explants of Pennisetum purpureum Schum. Plant Physiol $84: 47-51$

Rajasekaran K, Hein MB, Davis GC, Garnes MG, Vasil IK (1987b) Endogenous growth regulatores in leaves and tissue culture of Pennisetum purpureum Schum. Plant Physiol 130:13-25

Reynolds TL, Crawford RL (1996) Changes in abundance of an abscisic acid-responsive, early cysteine-labeled metallothionein transcript during pollen embryogenesis in bread wheat. Plant Mol Biol 32:823-829

Senger S, Mock H-P, Conrad U, Manteuffel R (2001) Immunomodulation of ABA function affects early events in somatic embryo development. Plant Cell Rep 20:112-120

Singh K, Ghai M, Garg M, Chhuneja P, Kaur P, Schnurbusch T, Keller B, Dhaliwal HS (2007) An integrated molecular linkage map of diploid wheat based on a Triticum boeoticum $\mathrm{x} T$. monococcum RIL population. Theor Appl Genet 115:301-312

Sutka J, Snape JW (1989) Location of a gene for frost resistance on chromosome 5A of wheat. Euphytica 42:41-44

Torada A, Ikeguchi S, Koike M (2005) Mapping and validation of PCR-based markers associated with a major QTL for seed dormancy in wheat. Euphytica 143:251-255

Touraev A, Vicente O, Heberle-Bors E (1997) Initiation of microspore embryogenesis by stress. Trends Plant Sci 2:285-303

Tyrka M, Bednarek PT, Kilian A, Wedzony M, Hura T, Bauer E (2011) Genetic map of triticale compiling DArT, SSR, and AFLP markers. Genome 54:391-401

van Bergen S, Kottenhagen MJ, van der Meulen RM, Wang M (1999) The role of abscisic acid in induction of androgenesis: a comparative study between Hordeum vulgare L. cvs. Igri and Digger. J Plant Growth Regul 18:135-143

van Ooijen JW (2004) MapQTL ${ }^{\circledR} 5$ Software for the mapping of quantitative trait loci in experimental populations. Kyazma BV., Wageningen, The Netherlands

Vaughan AK, Bate GC (1977) Changes in the levels of ethylene, abscisic acid-like substances and total non-structural carbohydrates in young cotton bolls in relation to abscisic acid induced by dark period. Rhod J Agric Res 15:51-57

Walker-Simmons MK, Abrams SR (1991) Use of ABA immunoassays. In: Davies WJ, Jones HG (eds) Abscisic acid, physiology and biochemistry. Bios Scientific Publishers, Oxford, pp 53-63

Wang P, Chen YR (1983) Preliminary study on prediction of height of pollen $\mathrm{H} 2$ generation in winter wheat grown in the field. Induction Acta Agron Sin 9:283-284 
Wang M, Hoekstra S, van Bergen S, Lamers GEM, Oppedijk BJ, van der Heiden MW, de Priester W, Schilperoort RA (1999) Apoptosis in developing anthers and the role of ABA in this process during androgenesis in Hordeum vulgar L. Plant Mol Biol 39:489-501

Wang M, van Bergen S, Van Duijn B (2000) Insights into a key developmental switch and its importance for efficient plant breeding. Plant Physiol 124:523-530

Wang S, Basten CJ, Zeng Z-B (2007) Windows QTL cartographer 2.5. Department of Statistics, North Carolina State University, Raleigh, NC. (http://statgen.ncsu.edu/qtlcart/ WQTLCart.htm)

Wassom JJ, Mei C, Rocheford TR, Widholm JM (2001) Interaction of environment and $\mathrm{ABA}$ and GA treatments on the maize anther culture response. Plant Cell Tiss Org Cult 64:69-72

Wędzony M (2003) Protocol for doubled haploid production in hexaploid triticale $(\times$ Triticosecale Wittm. $)$ by crosses with maize. In: Maluszynski M, Kasha KJ, Forster BP, Szarejko I (eds) Doubled haploid production in crop plants. A Manual Kluwer Academic Publication, Dordrecht, pp 135-140

Weiler EW, Schnabl H, Hornberg C (1982) Stress related levels of abscisic acid in guard cell protoplasts of Vicia faba L. Planta $154: 24-28$
Wilkinson S, Davies WJ (2002) ABA-based chemical signalling: the co-ordination of responses to stress in plants. Plant Cell Environ 25:195-210

You J, Li Q, Yue B, Xue W-Y, Luo L-J, Xiong L-Z (2006) Identification of quantitative trait loci for ABA sensitivity at seed germination and seedling stages in rice. Acta Genetica Sinica 33(6):532-541

Zdravkovi'C-Kora'C S, Neškovic M (1999) Induction and development of somatic embryos from spinach (Spinacia oleracea) leaf segments. Plant Cell Tiss Org Cult 55:109-114

Zhang J, Davies HJ (1987) ABA in roots and leaves of flooded pea plants. J Exp Bot 38:649-659

Zoriniants S, Tashpulatov AS, Heberle-Bors E, Touraev A (2005) The role of stress in the induction of haploid microspore embryogenesis. In: Palmer D, Keller W, Kasha K (eds) Haploids in crop improvement II. Springer, Berlin, pp 35-52

Żur I, Dubas E, Golemiec E, Szechynska-Hebda M, Janowiak F, Wedzony M (2008) Stress-induced changes important for effective androgenic induction in isolated microspore culture of triticale ( $\times$ Triticosecale Wittm.). Plant Cell Tiss Org Cult 94: 319-328 